\title{
Ariadne's adaptation of Alexander Oldys's The Fair Extravagant in She Ventures and He Wins ${ }^{T}$
}

\author{
Jorge Figueroa Dorrego \\ University of Vigo
}

\begin{abstract}
In the preface to She Ventures and He Wins (1695), the young woman signing as "Ariadne" says that the plot of this play is taken from "a small novel," the title of which she does not mention. Neither the editors Lyons and Morgan (1991) nor any of the few critics that have recently commented on this piece have identified the text upon which the play is drawn. The answer to this riddle is to be found in The Lives and Characters of the English Dramatick Poets (1699). The main plot of that comedy is Alexander Oldys's The Fair Extravagant, or The Humorous Bride, a practically unknown text that has not been reprinted since 1682. The aim of this paper is to (re-)unearth that source, and to analyse how Ariadne adapted the male-authored original for her own purposes as a woman dramatist, combined it with a farcical subplot, and endeavoured to tailor it to the new tastes of the town.

KEYWORDS: She Ventures and He Wins, adaptation, The Fair Extravagant, woman dramatist, Restoration drama.
\end{abstract}

She Ventures and He Wins is a comedy that was first performed at the New Theatre in Lincoln's Inn Fields in September $1695 .{ }^{2}$ In the

\footnotetext{
${ }^{1}$ This contribution is part of the Research Project HUM2006-09252-FILO, funded by the Spanish Ministry of Science and Education, whose support is hereby acknowledged. An earlier version of this paper was presented at the 18th International Conference of SEDERI, in Almagro, 22-25 April, 2008. I would like to thank Andrea Ruthven for her kind and keen help in linguistic and stylistic matters.

${ }^{2}$ The identity of its author was not revealed then, but the prologue announced that the play was "a woman's treat" (1991: 106), and the title-page of the printed version published in 1696 said it was written by "a young lady," who uses the pseudonym of "Ariadne" when signing the initial prose preface.
}

$$
\text { (3) ederi } 19 \text { (2009): 177-188 }
$$

https://doi.org/10.34136/sederi.2009.8 


\section{J. Figueroa Dorrego}

preface to the quarto published the following year, the "young lady" signing as "Ariadne" says that "[t]he plot was taken from a small novel; which, I must needs own, had design and scope enough to have made an excellent play, had it met with the good fortune to have fallen into better hands" (1991: 105). These last words are the customary sign of modesty that writers, and particularly women writers, used to insert in prefatory texts at the time. However, the first part of the statement, acknowledging the appropriation of a narrative plot, is noteworthy. According to Paulina Kewes (1998: 79), "[p]rior to the 1690s, dramatists did not signal their dependence on novels with any regularity," and one of the examples she gives to support that, from that time onwards, this kind of acknowledgments starts becoming common is precisely this one by Ariadne. The problem is that this "young lady" does not actually mention the title of that "small novel."

It is strange that neither the editors of She Ventures and He Wins in the anthology of comedies entitled Female Playwrights of the Restoration (1991) -Paddy Lyons and Fidelis Morgan- nor any of the few critics that have commented on the play have ever identified the source of the main plot. ${ }^{3}$ The answer to this riddle may be found in The Lives and Characters of the English Dramatick Poets compiled by Gerard Langbaine and Charles Gildon (1699: 168). ${ }^{4}$ The main plot of Ariadne's comedy is borrowed from Alexander Oldys's The Fair Extravagant, or The Humorous Bride (1682). The aims of the present note are to (re-)unearth that source and analyse how Ariadne adapted the male-authored original for her own purposes as a woman dramatist, combined it with a farcical subplot, and endeavoured to tailor it to the new tastes of the town.

\footnotetext{
${ }^{3}$ As far as I could trace, only Pérez Vides (2002) and Spencer (1994) pay considerable attention to this play, but brief comments about it can also be found in Ballaster (1996), Hughes (1996), Hume (1976), Kewes (1998), Novak (1975), Pearson (1988), Rubik (1998) and Straznicky (1997).

${ }^{4}$ I am greatly indebted to one of the anonymous referees who has read this paper for letting me know this information, as my first source was The Biographia Dramatica; or, A Companion to the Playhouse, which was compiled to the year 1764 by David E. Baker, then continued to 1782 by Isaac Reed, extended to 1811 by Stephen Jones, and published the following year in three volumes. The information about She Ventures and He Wins is given in entry number 200, volume III, page 264 .
} 
Oldys's The Fair Extravagant is a practically unknown text that has not been reprinted since $1682 .{ }^{5}$ After Gildon, who qualified it as "a very pleasant witty Novel" (1699: 168), only two scholars apart from myself have commented on this novel. ${ }^{6}$ One is Charles Mish, who defined it as "a stage comedy in narrative form" (1969: 299) because action, dialogue, and settings are very similar to those of Restoration comedies. No wonder then that someone may have thought of making a dramatic adaptation of this story. The other critic is Nicholas Hudson (2005: 577-581), who considers Oldys's novels an early example of the conservative ideology that pervades the novel throughout the long eighteenth century. Hudson pays attention to the Tory, good-natured rake hero and the detailed description of the familiar setting in The Fair Extravagant.

The plot is about a rich heiress, curiously enough called Ariadne, who, in the company of her cousin Miranda and both dressed in men's clothes, decides to look for a husband. When she finds a suitable man, she urges him to marry her although they hardly know each other. Being aware of the possible mistake of such a decision and wishing to test this man called Polydor for some days, the "humorous bride" of the subtitle vanishes soon after the wedding, leaving the groom baffled and desperate. For the first trial, Ariadne asks her cousin Dorothea to impersonate her, make Polydor

\footnotetext{
5 This text is included in Wing's Short Title Catalogue (1640-1661), 0264B, and only available in microfilm or EEBO. Very little is known also about the author, apart from his having written another novel, The Female Gallant, or, The Wife's the Cuckold (1692) and an "Ode, by Way of Elegy, on the Universally Lamented Death of the Incomparable Mr Dryden" (1700). The London Jilt; or, The Politick Whore (1683) has sometimes been ascribed to him, though wrongly so according to Thompson (1975: 293) and Hinnant ed. (2007: 11 and 203). No word is said about Alexander Oldys in the DNB. The Complete Newgate Calendar records an episode in which he is described as a small, deformed man (Rayner \& Crook eds. 1926, 2: 68). In the Gentleman's Magazine 54 (1784: 161) we can read that Oldys was sometimes called "The Little Poet" and "The English Scarron," names which seem to refer to his short height and his comic narrative style, close to that of the contemporary French writer, Paul Scarron. For Hudson (2005: 577), Oldys is "arguably an important and unjustly ignored innovator in the history of English prose fiction."

${ }^{6}$ I have delivered two other papers about this novel: "Anxious Masculinity in Alexander Oldys's novel The Fair Extravagant (1682)" (at the XVIII International Conference of SEDERI, Cádiz. 7-9 March 2007), and "Alexander Oldys's Comic Displacement of Romance in The Fair Extravagant" (at the XXXI International Conference of AEDEAN, A Coruña, 14-17 November 2007). The former remains so far unpublished; for the latter see Figueroa Dorrego (2008).
} 


\section{J. Figueroa Dorrego}

believe he has married another person, and pretend that she (Dorothea claiming to be the true Ariadne) loves him and would like to be his wife. This perplexes and desolates him even more. The thought of having been cheated into marriage by a female fraud leads him to fits of anger in which he voices the harsh misogynistic discourse of the time. However, Polydor resists temptation and remains constant to Ariadne. Then the heroine resolves to try his courage further by asking her main suitor and a friend of Polydor's, called Marwoud, to challenge him to a duel. Polydor defeats Marwoud but both are wounded. This daring trial proves his valour and strength but could cause his death. And for the following test, Ariadne again uses Marwoud. She asks him to find someone to sue Polydor for a debt supposedly contracted by his wife before marriage. Thus the protagonist ends up in jail, where he proves not only his constancy and stoic self-control but also his charity towards fellow prisoners. Dorothea and Miranda then persuade Ariadne to give up tormenting Polydor "and rest satisfied with his good qualities after so many cruel Experiments" (Oldys 1682: 167 [H12r]). She consents to undeceive him on the condition that they allow her to arrange their respective marriages to Marwoud and her brother Sir Francis, whom they secretly and passively love. The story ends with the final reconciliation and multiple weddings that are so typical of comedy.

It must be pointed out that Polydor is an educated 30-year-old gentleman from a good family, but he is the youngest son and therefore has little money. Marrying a baronet's daughter worth 1,200 pounds a year, beautiful and aged seventeen, is certainly an opportunity he cannot afford to miss. But that very same plight that provides a pragmatic justification to his patient constancy is paradoxically one of the reasons for much of his suffering. Ariadne's superiority in terms of social rank and wealth, together with her strong personality and free agency brings on Polydor's fears of his future authority as a husband. Throughout the novel Ariadne's behaviour is presented as extravagant (in the sense of undue and outrageous), humorous (in the sense of whimsical), and cruel. Polydor is obsessed with the possibility of being cuckolded and the public scorn that this would mean. This anxiety emasculates him and plunges him into frequent moments of passivity and self-pity. It also leads him to endorse a misogynistic discourse that the ironic, intrusive narrator shares and reinforces. Therefore, the story of this 
active and independent woman called Ariadne is told from a masculine perspective that puts the emphasis on the expectations of masculinity and the anxiety they produced in early modern men.

The impression that the novel caused in the "young Lady" who wrote She Ventures and He Wins is evident not only because she decided to adapt it to the stage, but also because she chose the heroine's name as her own pseudonym. So she most likely identified herself with the character's assertiveness and autonomy. In the same way that the novel's protagonist feels the need to disguise herself in order to start "rambling all the Town over" in search of a partner (Oldys 1682: 5 [B3]), the "young Lady" writer thinks it convenient to publish her first play under a pen name. "I am very sensible of the many nice judgments I expose myself to," she says at the beginning of the preface (1991: 105). The play was performed six years after the death of Aphra Behn, the main precedent as a woman dramatist, who had written some successful plays but whose reputation was morally dubious. After her death no other woman had had a play performed in England. Ariadne's step was therefore not an easy one to take. Writing for the commercial stage was risky for a woman's reputation due to the connotations of unchastity that entertaining the public for money had at the time and the frequent association between theatres and brothels ( $c f$. Straznicky 1997: 709-710, 714). As Rubik (1998: 25, 33) has pointed out, women playwrights were viewed as eccentric (i.e. extravagant) and often as immodest (due to the supposed immorality of some scenes in their plays and some episodes in their own lives). Moreover, in the mid 169os, the call for moral reform was too difficult to disregard. This justifies the young playwright's decision of wearing the mask of a nom de plume.

In spite of that modesty and anonymity, and of resorting to a male-authored text as a source, Ariadne places herself in the short tradition of English women writers. In the preface, she claims that after the death of the "incomparable Mrs Behn," her restrained muse "has claimed a kind of privilege; and, in spite of me, broke from her confinement" (105). And whoever wrote the verse prologue insists: "Our author hopes indeed,/ You will not think, though charming Aphra's dead,/ All wit with her, and with Orinda's fled" (106). Ariadne's wit may not be as successful as Behn's or Philips's, but many topics and features of She Ventures and He Wins are also found 


\section{J. Figueroa Dorrego}

in the works of those and other women writers of seventeenthcentury England. ${ }^{7}$

Actually, the first scene of the play resembles that of Behn's The Rover (1677) in showing the heroine willing to "ramble the town" in search of a lover, in disguise and in the company of a female relative. The main differences are that in Ariadne's play they are already cross-dressed, the setting is London, and they are the only two characters in that initial scene. This also differs slightly from the beginning of Oldys's novel, because the latter includes an ironic, intrusive narrator that gives a fairly sardonic view of the heroine. In Ariadne's play, however, the opening conversation between Charlotte and Juliana, as Pearson has rightly remarked, "introduces us to the play-world through their eyes" (1988: 139). ${ }^{8}$ The dialogue elaborates ideas of women's power before and after marriage, the empowering effect of cross-dressing in an oppressive patriarchal world, and men's tendency to deceive in courtship. ${ }^{9}$ This is how the play begins:

Juliana: Faith, Charlotte, the breeches become you so well 'tis almost pity you should ever part with'em.

Charlotte: Nor will I, till I can find one can make better use of them to bestow'em on, and then I'll resign my title to'em for ever.

Juliana: 'Tis well if you find it so easy, for a woman once vested in authority, though 'tis by no other than her own making, does not willingly part with it. [...]

Charlotte: $[\ldots]$ These clothes will give us greater liberty than the scandalous world will allow our petticoats, which we could not attempt this undertaking in without hazard to our modesty.

\footnotetext{
${ }^{7}$ Greer (1988: 24), however, contends that the author of She Ventures and She Wins may not be that young (as she already wanted to be a writer when Behn was alive) or even a woman (as Mrs. Bowman speaks the prologue in man's clothes), but I do not think there is enough evidence to conclude that the author is male. The argumentation in the present study would rather point at a woman dramatist.

${ }^{8}$ Pearson adds that this play is unusual in having more female characters than male and in allowing women to speak half of the lines, which contributes to reinforcing the abovementioned feminine perspective. Ballaster focuses on the opening of the play as well, and argues that it mimics "the conventional opening of the paired male coconspirators in the comedy" (1996: 282). See also Spencer (1996: 325).

${ }^{9}$ For an interesting study of the effects of cross-dressing in this play, see Pérez Vides (2002).
} 
Besides, should I meet with the man whose outside pleased me, 'twill be impossible by any other means to discover his humour; for they are so used to flatter and deceive our sex, that there's nothing but the angel appears, though the devil lies lurking within, [...]. (1991: 109)

Like Oldys's Ariadne, Charlotte has assumed both the powerlessness that women had as wives at the time and the whole set of moral values that placed modesty as a key feminine virtue. However, she is resolute in having full control of her life before marriage. She wants the freedom to find a prospective husband who will not deceive her and will not marry her for her money:

I'm not obliged to follow the world's dull maxims, nor will I wait for the formal address of some ceremonious coxcomb, with more land than brain, who would bargain for us as he would for his horse [...] I'll have one who loves my person as well as gold, and please myself, not the world, in my choice. (110)

Yet complying with patriarchal morality and intending to play an active, self-determining role is not an easy task for a woman, so she is forced to resort to disguise, faking, and stripping all the nonsexual elements from the notion of modesty, i.e. being sexually chaste but not silent or passive. As Spencer puts it, female characters of Restoration and eighteenth-century literature usually deceive as a strategy "for gaining some measure of power within a social structure that denies them power;" and Charlotte is "a very striking example of a female character who tells lies, weaves fictions around herself, and uses this to control her world. While doing this she remains a heroine, presented to us as a virtuous and sympathetic character" (1994: 320). It is precisely her commitment to chastity that justifies her acts. After all, she deceives to avoid being deceived by men, and she usurps masculine authority only temporarily, claiming to be willing to abide by it after marriage. Yet, Spencer warns us that this "may be another deception designed to conceal the desire truly to take over masculine authority" (326). In fact, none of the men in the plot of this play are representative of traditional masculinity and threatening, oppressive authority. ${ }^{10}$

${ }^{10}$ Ballaster also argues that the wit of the female characters in this and other contemporary plays by women both surmounts the 'managerial' capacity of their male counterparts and allows them the freedom to marry the men of their choice (1996: 282). 
Ariadne certainly wishes to make her heroine sympathetic to the audience, not only by reaffirming that commitment to chastity (in the novel, apart from the narrator's ironic comments, she says she is tired of her maidenhead), but also by softening her humorous nature a little so that, for instance, she never plans a duel as a test, which gives the novel's heroine a touch of cruelty and senselessness. There is an important change in the presentation of male characters too. In spite of the negative view of men that Charlotte gives in the previous quotations, she is convinced that there are some men of a different kind: "there still remains a race retains the image Heaven made them in, virtuous and just, sincere and brave." She will find one "or else lead apes in Hell" (109-110). And she does find one, aptly called Lovewell. Like Oldys's Polydor, he is the youngest son of a good family, overtrusting, honest, and constant. ${ }^{11}$ When he is forsaken by Charlotte on the wedding day, Lovewell also rails against her in anger but does not indulge so often in the misogynistic discourse. Moreover, he does not use so many sexual innuendoes when talking to her, nor drink so much, nor have a group of rakish friends. This should make him more acceptable as the right husband for the heroine, particularly in the eyes of the mid-169os audience. ${ }^{12}$

Another difference in characterisation is found in the only character whose name is not changed: Marwood. In Oldys's novel, he is a suitor of Ariadne's and therefore sees Polydor as a rival he must get rid of. For that reason, he eagerly accepts her request to challenge him to a duel and is very aggressive in the fight. In the play, however, Marwood is a good friend of Lovewell's, considers him the best husband for Charlotte, is very reluctant to engage in the test of the imprisonment, and is in love with Bellasira. Thus he is a much more agreeable character, who represents male friendship and is conceived in order to gain the sympathy of the contemporary public.

\footnotetext{
${ }^{11}$ As Hughes (1996: 385) points out, "Lovewell remains immovably faithful to his wife, loving the woman even when she has (apparently) been stripped of the name and station by which he initially knew her, becoming a nameless and placeless enigma."

${ }_{12}$ Hume (1976: 430) states that the mid-nineties witness the collapse of "hard" comedy, which is replaced by a "soft" one with increasing doses of overt didacticism. She Ventures and He Wins is an example of this new approach. The whole design of the play is "rigorously moral" (420). Rubik (1998: 59) also considers the piece a "reformed" comedy.
} 
Nonetheless, the greatest alteration in the play in relation to the narrative source is the addition of a subplot. This subplot contrasts with the main plot as regards the social rank of the characters (from the middle class) and the type of comedic action (more farcical and jest-like), but it deals with similar themes of women's power and reputation, and how they have to resort to deception to preserve their honour. Here Urania, wife to a vintner called Freeman, resolves to get rid of a pestering suitor that makes advances to her, although he is also married. The Dramatis Personae section describes this man, called Squire Wouldbe, as "a proud pragmatical coxcomb of poor extraction" (1991: 104) -“pragmatical" meaning meddlesome or intrusive. This subplot is interwoven with the main plot from the second scene of Act One, and the two actions join at the end of Act Five when all the characters happen to meet at the tavern.

Initiating scene two, Urania says she does not want to be "thought dishonest, without knowing the pleasure of it" (111), and is willing to curb Squire Wouldbe's advances herself rather than remain passive and let her husband defend her -and his- honour. She resolves to do it through a series of tricks. For the first she asks him to visit her in women's clothes, then tells him to hide from her husband in a cistern and in a tub full of feathers, and then makes him fall in a trap where he is harassed by some devils who threaten to "dip him in Styx to abate his hot lust" (128). These pranks emasculate him by frustrating his sexual performance, revealing his cowardice, and ridiculing him with the wet and feathery women's dress on. The effect of his cross-dressing is therefore the opposite of Charlotte's: humiliating rather than empowering. ${ }^{13}$ But as he insists on seeing her, Urania arranges a meeting to which his jealous wife Dowdy is also invited so that she can witness her husband's infidelity. This happens in the last scene in which, as was said before, the characters of the main plot are also present. Their comments are actually the last words in the play and, therefore, noteworthy. In their happy day of betrothal, Bellasira casts some doubts on male fidelity by remarking: "You see what constant things you men are to your vows! I warrant this fellow swore as much faith and constancy

\footnotetext{
${ }^{13}$ According to Pearson (1988: 105-106), transvestite men in plays are not as common as cross-dressed women, never central, and seldom sympathetic figures. They usually become ridiculous fools. Female writers of the time, such as Behn, Polwhele, and Centlivre, often mocked some male characters by putting them in women's clothes. Cf. also Bullough and Bullough (1993: 75-79).
} 


\section{J. Figueroa Dorrego}

as any of you can." But Charlotte asks her not to generalise: "disgrace not so the race of men, to compare him to one; such senseless wretches are only lumps of dirt, not fit for any nobler form" (159). This is related to what she said at the beginning, that she believed in the existence of honest men and she wanted to find one. Lovewell is supposed to represent that kind of man, probably Marwood and Sir Charles too. Perhaps the naïve youth of the anonymous female author made her envisage that possibility, or maybe she expected to gain the sympathy of at least part of the male audience.

Unfortunately the reception of the play was not favourable. According to Novak (1975: 51), this "may have been due to its feminist reversal of sexual roles," particularly because Charlotte humiliates Lovewell "to an uncomfortable degree" through her insistence on testing his love. And to this we can add Urania's humiliation of Squire Wouldbe, which was more justifiable morally speaking, but still a subversion of gender hierarchy and a usurpation of her husband's role. What is evident is that all the alterations in plot and characterisation in relation to the source, that Ariadne made in order to suit her own interests and the new moral expectations, were not enough to win the public's favour. No matter how sexually chaste Charlotte and Urania were, it seems that their assertiveness and autonomy were not welcome, and no matter how constant and amicable Lovewell and Marwood may be, their subordination to Charlotte's sway was not likeable. Yet we must bear in mind that the male-authored source was another failure, which only seems to have drawn the attention of a "young Lady" who was no doubt fascinated by the gender-transgressive Ariadne.

\section{References}

'Ariadne' 1991. "She Ventures and He Wins." Eds. Paddy Lyons and Fidelis Morgan. Female Playwrights of the Restoration. Five Comedies. London: Dent: 103-159.

Baker, David E., Isaac Reed and Stephen Jones 1812. Biographia Dramatica; or a Companion to the Playhouse. 3 vols. London: Longman et al.

Ballaster, Ros 1996. "The First Female Dramatists." Ed. Helen Wilcox. Women and Literature in Britain 1500-1700. Cambridge: Cambridge University Press: 267-290. 
Bullough, Vern L. and Bonnie Bullough 1993. Cross-Dressing, Sex, and Gender. Philadelphia: University of Pennsylvania Press.

Figueroa Dorrego, Jorge 2008. "Alexander Oldys's Comic Displacement of Romance in The Fair Extravagant." Ed. M. J. Lorenzo Modia. Proceedings from the 31st AEDEAN Conference. A Coruña: Universidade da Coruña: 433-442.

Greer, Germaine 1988. "Introduction." Eds. Germaine Greer, Jeslyn Medoff, Melinda Sansone and Susan Hastings. Kissing the Rod. An Anthology of Seventeenth-Century Women's Verse. London: Virago: 1-31.

Hinnant, Charles ed. 2007. The London Jilt. Peterborough, Ontario: Broadview Press.

Hudson, Nicholas 2005. "Social Rank, "The Rise of the Novel," and Whig Histories of Eighteenth-Century Fiction." Eighteenth-Century Fiction 17/4: 563-598.

Hughes, Derek 1996. English Drama. 1660-1700. Oxford: Oxford University Press.

Hume, Robert 1976. The Development of English Drama in the Late Seventeenth Century. Oxford: Clarendon Press.

Kewes, Paulina 1998. Authorship and Appropriation: Writing for the Stage in England, 1660-1710. Oxford: Clarendon Press.

Langbaine, Gerard and Charles Gildon 1699. The Lives and Characters of the English Dramatick Poets. London: William Turner.

Mish, Charles 1969. "English Short Fiction in the Seventeenth Century." Studies in Short Fiction 6: 233-330.

Novak, Maximilian 1975. “The Closing of Lincoln's Inn Fields Theatre in 1695." Restoration and Eighteenth-Century Theatre Research 14: 51-52.

Oldys, Alexander 1682. The Fair Extravagant, or, The Humorous Bride. An English Novel. London: Charles Blount.

Pearson, Jacqueline 1988. The Prostituted Muse. Images of Women and Women Dramatists 1642-1737. Hemel Hampstead: Harvester-Wheatsheaf.

Pérez Vides, Auxiliadora 2002. "Gender, Disguise and the Politics of Marriage in Ariadne's She Ventures and He Wins." SEDERI 11: 271-276.

Rayner, John L. and G.T. Crook. Eds. 1926. The Complete Newgate Calendar. 5 Vols. London: Navarre Society.

Rubik, Margarete 1998. Early Women Dramatists 1550-1800. Basingstoke: Macmillan.

'S.A.' 1784. "Anecdote of Alexander Oldys." Gentleman's Magazine 54: 161.

Spencer, Jane 1994. "Not Being a Historian: Women Telling Tales in Restoration and Eighteenth-century England." Ed. Roy Ericksen. 


\section{J. Figueroa Dorrego}

Contexts of Pre-Novel Narrative: The European Tradition. Berlin: Mouton de Gruyter: 318-340.

Straznicky, Marta 1997. "Restoration Women Playwrights and the Limits of Professionalism." E.L.H. 64/3: 703-726.

Thompson, Roger 1975. "The London Jilt." Harvard Library Bulletin 23/3: 289294 .

How to cite this note:

Figueroa Dorrego, Jorge. "Ariadne's adaptation of Alexander Oldys's The Fair Extravagant in She Ventures and He Wins." SEDERI 19 (2009): 177-188.

Author's contact: jdorrego@uvigo.es

Submission: 19/09/2008

Acceptance: 23/01/2009 